\title{
A Critical review on Pharmacodynamics of Basti Chikitsa and its action on Enteric Nervous System
}

\author{
Review Article
}

\begin{abstract}
Bende Yogita $^{1^{*}}$, Pawan Lekurwale ${ }^{2}$, Smita Mekhale $^{3}$, Suraj Rathod ${ }^{4}$, Danga SK ${ }^{4}$, Chetan Gulhane $^{5}$
1. Associate Professor, Department of Panchkarma, 2. Assistant Professor, Department of Kayachikitsa Shri Ayurveda Mahavidyalaya, Nagpur.

3. Assistant Professor, Dept. of Rachana Sharir, D.Y.Patil University School of Ayurveda, Navi Mumbai.

4. Govt. Ayurveda College and Hospital, Nagpur.

4. I.P.G.T. and R.A., Gujarat Ayurved University, Jamnagar.
\end{abstract}

\begin{abstract}
Ayurveda being an ancient science it has developed through many experiences and experiment in medicines. Panchakarma therapy is a very imperative and essential part of Ayurvedic treatment. Panchakarma (Vaman,Virechan, Nasya, Anuvasan \& niruha) practices to get complete cure of disease, Basti is the main treatment as it possesses a wide spectrum of effects and is thought to be the Ardhachikitsa (50\% of all treatment modality) in Ayurveda. Though Basti is given in the Pakvashaya (Rectum and Colon) its active ingredients i.e. "Virya of the Basti" spreads in the entire body to get desire action. BastiVirya may act through enteric nervous system (ENS). The gastrointestinal system has a network of nerve fibres, which is known as 'Enteric Nervous System (ENS). Similar to brain, ENS sends and receives impulses; record experiences and responds to various stimuli.
\end{abstract}

Key Words: Basti, Virya, Enema therapy, Enteric nervous system.

\section{Introduction}

Panchakarma therapy is a very imperative and essential part of Ayurvedic treatment. The effectiveness of Panchakarma therapy also depends on suitable application of different elimination procedures as well as on the proper preparations of various formulations required to complete the Panchkarma.

In Panchkarma Chikitsa, Basti is superior to other (virechan,vaman ) Shodhanas (bio purification therapies). It increases Shukra(potency), Oja (vital energy) \&Agni (digestive fire). This Karma of Basti is basically due to its Shodhana property that starts right from the Pakvashaya i.e. Colon.(1) Basti is a multidrug formulation that is given per rectum and reaches up to ileo-caecal junction and classical Bastiputak proved more efficacious than enema pot method and has more retention time in both Asthapana as well as Anuvasana Basti, thus absorption is more in classical method.(2) Shodhana is entity that is associated with the removal of Mala (morbid Doshas) from the body. There are various toxins accumulated in the body due to defective removal which can be considered as a part of Mala or morbid Doshas.(3)

Panchakarma itself is a composite and distinctive system of treatment, so its pharmaceutical preparations also possess some special characteristics.

*Corresponding Author:

Dr. Bende Yogita

229, Chhatrapati nagar,

Nagpur -440015.

Phone Number: +91-9011065671

E mail : yogitabende@gmail.com
Basti has the prime function of colon cleansing. The colon cleansing has the effect on whole body that can be compared to the Srotoshodhana. The rationale for colon cleansing is the concept of "autointoxication", the idea that food enters the intestine and rots.(4) Basti has two types Niruh or Asthapan Basti (decoction enema) and Sneha or Anuvasan Basti (oil enema.(5) Niruha Basti is a mixture of oil, honey, 'kwaatha' (decoction) and 'Kalka' (fine paste obtained after wet grinding of the plant material). These ingredients are immiscible with each other. A homogenous mixture is required for actual administration of 'Basti'. Initially honey and rock salt are mixed together in the beginning followed by addition of oil. This mixture is then thoroughly mixed. The finely wet grinded paste of prescribed medicinal plants is then mixed in it. The mixture is then again mixed thoroughly. The prescribed liquids such as $k$ waatha (decoction) are then added to it and the mixture is subjected to thorough churning to produce a homogeneous mixture.(6) The mixture thus acquires a physical state of emulsion. An emulsion is a mixture of two or more immiscible (unbendable) liquids. One liquid (the dispersed phase) is dispersed in the other (the continuous phase).

\section{Role of Honey:}

It is recommended in the classics of Ayurveda that hot honey is harmful and never be taken. However in Charaka Samhita Kalpa Sthana, hot honey is indicated to prescribe for Vamana Karma. In Basti Kalpana also, honey along with hot decoction are administered into the body.It is considered as the best 
among the vehicles, as it contains various substances in it, which denotes its drug (potency of the drug) Carrying Capacity.(7) It has properties like 'Yogavaahitwa' by way of which it enhances the properties of substances with which it is processed.

Honey is a natural product with very complex chemical composition. It is composed primarily of fructose and glucose but also contains 4 to $5 \%$ fructooligosaccharides which serve as prebiotic agents. (8) It contains more than 180 substances, including amino acids, vitamins, minerals and enzymes.(9) Honey has simulative effect on colonic probiotic bacteria. It is involved in formation as well as inactivation of carcinogens in the gut lumen and may be altered in a positive way by the presence of colonic probiotic bacteria. (10) Honey a natural emulsifying agent which may also be used to help stabilize the colloid, binding the liquids together. In cases where the emulsion is not successfully stabilized, components may separate again later on.(11) Antitoxic effect of honey catalyse that neutralizes hydrogen peroxide which is found extensively in mammalian tissues is continuously produced by numerous metabolic reactions in the organism, bacterial and viral infections, sharp changes of weather conditions, stress conditions, over fatigue etc.(12)

\section{Role of Saindhava Lavana (rock salt):}

Salt in general are having the properties like Vishyandi, Sukshma, Tikshna and Vataghna, it promotes the evacuation of bladder and rectum. (13) Owing to the Sukshma (micro or extremely small) property it helps the drug (potency of the drug) to reach in the micro channels, Saindhava(rock salt) mixed with honey is capable of liquefying the viscid Kapha and breaking it into minute particles for their easy elimination. Similarly it may liquefy the morbid Doshasanghata and breaks it into smaller particles by virtue of its Ushna and Tikshna property respectively and thus helps their elimination. Apart from this, Saindhava(rock salt) destroys the Picchila, Bahula and Kashaya properties of Madhu (honey), and makes close union with it to form a homogeneous mixture.(14) It also has chhedan (penetrative), Vilayan (Liquefaction of doshas) Avidahi (doesn't cause burning sensation) and Tridoshaghna property. It dissolves and expels Dosha from colon. Thus it helps in absorption and bio purification process of Basti. Continuous churning of honey and rock salt increase the homogeneity of the emulsion of Basti material and reduction in the size of particles with the duration of BastiBhavana.(15)

\section{Role of Sneha (Lipids):}

It includes Ghrita, Taila (oil), Vasa, Majja (bone marrow) and each one is having its specific properties accordingly it produces beneficial effects. Sneha in general is Vatahara, Mrudukara(produces softness in the channels and tissues, in turn helps for easy elimination of waste substances) and removes the obstruction the channels produced by the Mala i.e. Malanam Vinihanti Sangam.(16) Owing to the Snigdha Guna, it produces unctuousness in the body in turn helps for easy elimination and by Sukshma Guna it helps the drug (potency of the drug) to reach into the micro channels. Apart from these functions, it protects the mucous membrane from the untoward effect of irritating drugs in the Basti Dravya.

In colon production of short-chain fatty acids (SCFA) is produce by abundant bacterial fauna. Colonocytes can take SCFA up efficiently and in part utilize them as nutritional sources. Both squamous stratified mucosa of rumen and columnar simple epithelium of intestine absorb readily SCFA. Passive diffusion of the unionized form across the cell membrane is currently admitted. In the lumen, the necessary protonation of SCFA anions could come first from the hydration of CO2. (17) SCFAs might play a key role in the treatment of the metabolic syndrome, bowel disorders, and certain types of cancer. In clinical studies SCFA administration positively influenced the treatment of ulcerative colitis, Crohn's disease, and antibiotic-associated diarrhoea. (18)

\section{Role of Kalka:}

It serves the function of Utkleshana or Doshaharana or Samshamana depending upon its contents and is selected accordingly. It gives required thickness to the Basti material. Less quantity or absence of Kalka (paste of herbs) makes the Basti Dravya thin which comes out immediately after administration. Excess quantity of the Kalka (paste of herbs) makes the Basti Dravya thick and difficult for administration and may not come out within the expected time. Kalka Dravya acts as a catalyst agent which improves the potency of Basti.

\section{Role of $K$ watha (decoction of herbal drugs):}

It is the Drava Dravya (liquid part), usually the Kashaya (decoction of herbal drugs) is used, but as per the need Kshira (milk), Mamsarasa (decoction of meat), Amlakanji, cow urine, Dadhimastu (curds water) etc. are also used in place of decoction of herbal drugs or for the preparation of Kwatha (decoction of herbal drugs) itself. The drugs used for the preparation of Kalka and Kwatha are selected on the basis of Dosha, Dushya and Srotas involved in the pathogenesis of the disease, hence they are the main constituents of the Basti Dravya.

\section{Probable absorption of Basti:}

The human colon has a nominal mucosal surface area of about $2000 \mathrm{~cm}^{2}$ but in reality the total absorptive area is even greater because colonic crypt cells are capable of absorption as well as secretion. (19)Drug absorption is determined by the drug's physicochemical properties, formulation, and route of administration. In rectum drugs may cross cell membranes by passive diffusion, facilitated passive diffusion, active transport, or pinocytosis. Sometimes various globular proteins embedded in the matrix function as receptors and help transport molecules across the membrane. (20)

In clinical study on pharmacokinetic of Basti of Triphala Tail Anuvasan and Triphala Niruha in humans shows significant absorption of Gallic acid in blood 
which is active ingredient of Triphala as compared to oral Group. On quantitative estimation of Gallic acid in all the samples of human Anuvasana, Niruha and Oral group, concentration of Gallic is found highest in Anuvasana group at 90 minutes after administering Triphala Niruha Basti.(21)

\section{Discussion :}

\section{Pharmacodynamics of Basti:}

Basti acts through its Virya. Active principles of the drug are generally considered as 'Virya.'(22) Active principle is an ingredient of a drug that is actively involved in its therapeutic effect. Nipata(contact) and Adhivasa (inherent residing) are the two chief mode by which Basti Virya can affect the body as seen by the above mentioned explanation.

\section{Action of Bastivirya by Nipata:}

Basti administered in the Pakvashaya affects the whole body by its Virya similarly as the sun in the sky affects the Bhurasa (water) though it is far away.(23) This example shows Action of Basti is not only dependent upon absorption of the active principle but also it affects the body as soon as these active principles comes in contact with the Pakvashaya proving the action of Bastivirya by Nipata.

\section{Action of Bastivirya by Adhivasa:}

When Basti is administered in the Pakvashaya, its Virya(probably active principles) is taken up by Samana Vayu with the help of Apana Vayu. Then it reaches other Vayus also, and affects them by its action. It also keeps Pitta and Kapha in there proper places. It exerts its effect on Bhutas which are similar to that Guna of Virya. The transport of Bastivirya is by Kedarikulya Nyaya which makes it spread all over the body by virtue of different Vayus.This quotation supports the theory of absorption of Basti active principles i.e. phytochemicals of the Basti as the action is dependant upon Gunas which are the properties in Dravya.(24)

\section{Action of Basti through enteric nervous system (ENS)}

This action can be explained in modern parlance by the direct action of active principles of drug on receptors in the gastrointestinal tract related to the enteric nervous system. ENS (Enteric Nervous System) is substantial group of neurons, it is capable of Autonomous reflex without influence of central nervous system. More than 500 million neurons present in the ENS (Enteric Nervous System) so it's called "second brain".(25) There are so many similarities between CNS -ENS regarding cellular structure, neuropeptide secretion and specific functions and recent studies have shown that there is great influence of CNS and ENS on each other.(26)

Basti may act over the receptors of the ENS to stimulate the CNS causing secretion of required hormones or other chemicals. Hence the effect of Basti may also be associated with "Touch \& Go Theory" causing activation of ENS receptors. It is recognised that the enteric nervous system has a unique ability to mediate reflex activity independently of input from the brain or spinal cord.(27) This ability implies that the ENS contains sensory receptors, primary afferent neurones, interneuron's and motor neurones. The events that are controlled, at least in part, by the ENS are multiple and include motor activity, secretion, absorption, blood flow, and interaction with other organs such as the gall bladder or pancreas.(28) The extensive regulatory activities of the ENS are made possible by the presence and abundance of different types of neurones within the wall of the gastrointestinal tract. Morphological, electrophysiological, and pharmacological studies have revealed a substantial diversity of neurones within the ENS. (29) It produces a wide range of hormones and around 40 neurotransmitters of the same classes as those found in the brain. In fact, neurons in the gut are thought to generate as much dopamine as those in the head. Intriguingly, about 95 per cent of the serotonin present in the body at any time is in the ENS. Serotonin produced in the gut gets into the blood, where it is involved in repairing damaged cells in the liver and lungs. It is also important for normal development of the heart, as well as regulating bone density by inhibiting bone formation. (30)

\section{Conclusion:}

The composition of the enema (solid vs. liquid, nature of the suppository base) appears to be an important factor in the absorption process by determining the pattern of drug release. For a number of drugs the extent of rectal absorption has been reported to exceed oral values, which may reflect partial avoidance of hepatic first-pass metabolism after rectal delivery. ENS works in synergism with the CNS. Stimulation with Basti (either by chemo or mechano receptors) may lead to activation of concerned part of CNS which precipitates result accordingly.

\section{References:}

1. Vaghbhata, Ashtanga Samgraha with Indutika, kalpasthan $5 / 73$, edited by Vd. AnantAthavale, Shrimad Atreya Prakashana, Erandavanam, Pune.1980, pg 30

2. JunejaYashwant M, Thakar A. B.,Standardization of procedure of administration of Basti w.s.r to Kshinashukra (oligozoospermia), MD Dissertation, IPGT \& RA. Jamnagar: Gujarat Ayurved University; 2010.

3. Bhavaprakash, Hindi Commentary by Dr .K. C. Chunekar, Chaukhamba Bharati Academy

4. Chen TS, Chen PS (1989). "Intestinal autointoxication: a medical leitmotif". J. Clin. Gastroenterol.11 (4): 434-41.

5. Sushrut, Sushrut Samhita, Chikitsasthan 35/18, edited by Ambikadatta Shastri, thirteen edition, Chaukhamba Sanskrit Prakashan, Varanasi, 2002, pg 154

6. Agnivesh, Charaka, Charak Samhita, Siddhisthan 3/23, Vol -2,editorBrahmanandTripathi, Chaukhamba Surbharati Prakashan, Varanasi 2007. pp. 26-28. 
7. Agnivesh, Charaka, Charak Samhita, Sutrasthan27/249, Vol -2, editor Brahmanand Tripathi, Chaukhamba Surbharati Prakashan, Varanasi 2007. pp. 1197

8. Chow J: Probiotics and prebiotics: a brief overview. J Ren Nutr 2002, 12:76-86.

9. White JW: Composition of honey. In Honey: A Comprehensive Survey. Edited by Crane E. London, einemann; 1979:157-192.

10. El-Arab, Aly M. Ezz, et al. "Effect of dietary honey on intestinal microflora and toxicity of mycotoxins in mice." BMC complementary and alternative medicine6.1 (2006): 6.

11. Emulsifying Technique, available from http:// www.modernistcookingmadeeasy.com/info/ modernist techniques/more/emulsifying-technique Emulsifying Technique(cited on 11 sep 2015)

12. Honey biological (physiological importance) available from http://www.mari-el.ru/bee/ honey_biological.html(cited on 11 sep 2015)

13. Vaghbhata, Ashtanga Hridaya,Sutrasthana 6/143, edited by BrahmanandTripathi,Chaukhamba Sanskrit Prakashan, Varanasi,2014, pg 115

14. Kashayap, Kashyapa Samhita,khilstan 8/41,edited by Hemaraja Sharma, 1st edition Chaukhambha Sanskrit Series, Varanasi.

15. Sumitha, L., K. S. Gudaganatti, and B. S. Prasad. "Effect of BhavanaSamskara on Particle size distribution in various stages of preparation of Niruha Basti with special reference to Madhutailika Basti." International Journal of Ayurvedic Medicine 5.4 (2014).

16. Agnivesh, Charaka, Charak Samhita, Siddhisthan1/7, Vol -2, editor BrahmanandTripathi, ChaukhambaSurbharatiprakashan, Varanasi 2007. pp. 26-28.

17. Bugaut, Maurice. "Occurrence, absorption and metabolism of short chain fatty acids in the digestive tract of mammals." Comparative Biochemistry and Physiology Part B: Comparative Biochemistry 86.3 (1987): 439-472.

18. Binder H. J. 2010. Role of colonic short-chain fatty acid transport in diarrhea. Annu. Rev. Physiol.72: 297-313
19. Drug Absorption available from http:// www.msdmanuals.com/professional/clinicalpharmacology/pharmacokinetics/drug-absorption (cited on 11 sep 2015)

20. Singh SK, Binder HJ, Boron WF, et al. (1995) Fluid absorption in isolated perfused colonic crypts. J Clin Invest 96:2373-2379.

21. Shukla Gyanendra, Thakar A. B., A ClinicoExperimental Study on Pharmacokinetics of Basti W.S.R. its role in the management of Sandhivata (Osteoarthritis), PhD Dissertation, IPGT \& RA. Jamnagar: Gujarat Ayurved University; 2014.

22. Sushrut, sushrut Samhita, Chikitsasthan 35/27, edited by Ambikadattashastri, thirteen edition, Chaukhamba Sanskrit Prakashan, Varanasi, 2002, pg 155

23. Agnivesh, Charaka, Charak Samhita, Siddhisthan7/64, Vol $\quad-2, \quad$ editor BrahmanandTripathi, ChaukhambaSurbharatiprakashan, Varanasi 2007.pg, 712

24. Vaghbhat, AshtangaSamgraha with Indutika edited by Vd. AnantAthavale, ShrimadAtreyaPrakashana, Nanda-Nandan, 117/121/2 Erandavanam, pune-4, 1980, pg 29

25. Gut instincts: The secrets of your second brain, available from http://neurosciencestuff.tumblr.com/ post/38271759345/gut-instincts-the-secrets-of-your -second-brain, (cited on 11 sep 2015)

26. Enteric nervous system, available from http:// www.scholarpedia.org/article/

Enteric_nervous_system\#ENS-CNS_interactions (cited on 11 sep 2015)

27. Wood JD. Physiology of the enteric nervous system. In: Johnson LR, ed. Physiology of the gastrointestinal tract, 3rd edn. New York: Raven Press, 1994:423-82.

28. Goyal RK, Hirano I.The enteric nervous system. N Engl J Med 1996;334:1107-15.

29. Furness JB, Costa M. The enteric nervous system. New York: Churchill Livingstone, 1987.

30. The Second Brain | Our Enteric Nervous System, available from http://www.mfi-therapy.com/thesecond-brain-our-enteric-nervous-system/(cited on 11 sep 2015) 